ORIGINAL ARTICLE

\title{
Cultivable cellulolytic fungi isolated from the gut of Amazonian aquatic insects
}

\author{
Enide Luciana BELMONT-MONTEFUSCO*1,2®, Lorena NACIF-MARÇAL ${ }^{2}$, Enedina Nogueira de \\ ASSUNÇÃO ${ }^{2}$, Neusa HAMADA³ ${ }^{3}$, Carlos Gustavo NUNES-SILVA²
Universidade Federal do Amazonas (UFAM), Programa Multi-Institucional de Pós-Graduação em Biotecnologia, Av. General Rodrigo Octavio Jordão Ramos 1200 , Coroado I, Manaus, Amazonas, CEP 69067-005, Brazil Coroado I, Manaus, Amazonas, CEP 69067-005, Brazil Petrópolis, Manaus, Amazonas, CEP 69067-375, Brazil \\ 2 Universidade Federal do Amazonas (UFAM), Instituto de Ciências Biológicas, Laboratório de Biologia Molecular, Av. General Rodrigo Octavio Jordão Ramos 1200 , \\ ${ }^{3}$ Instituto Nacional de Pesquisas da Amazônia (INPA), Coordenação de Biodiversidade, Laboratório de Citotaxonomia e Insetos Aquáticos, Av. André Araújo 2936, \\ * Corresponding author: lucianabelmont22@gmail.com; (D) https://orcid.org/0000-0002-6196-4204
}

\section{ABSTRACT}

Filamentous fungi have been targeted by bioprospecting studies because they are effective producers of extracellular enzymes that can potentially be used by the bioindustry. In this study, we isolated filamentous fungi from the guts of Amazonian aquatic insect larvae to evaluate their cellulolytic activity. We collected 69 larvae of shredder insects of three genera: Phylloicus (Trichoptera: Calamoceratidae), Triplectides (Trichoptera: Leptoceridae) and Stenochironomus (Diptera: Chironomidae) in ten streams from a protected area in the central Brazilian Amazon. Production of mycelia was elaborated in PDA (Potato Dextrose Agar) medium. The isolates were transferred to a synthetic medium with carboxymethyl cellulose, and Congo red was used to determine the enzymatic index. The hydrolysis halo, indicating the production of cellulases, was observed in 175 fungal isolates (70\% of the total), of which 25 had an enzymatic index $\geq 2.0$ and belonged to seven fungal genera. The fungal taxa Cladosporium, Gliocephalotrichum, Penicillium, Pestalotiopsis, Talaromyces, Trichoderma and Umbelopsis were isolated from guts of Phylloicus, Triplectides and Stenochironomus, which are traditionally used in biotechnological applications. Our results indicate the cellulolytic potential of fungi associated with the guts of aquatic Amazonian insects.

KEYWORDS: cellulase, enzymatic hydrolysis, Phylloicus, shredders, Amazonia

\section{Fungos celulolíticos cultiváveis isolados do intestino de insetos aquáticos da Amazônia}

\section{RESUMO}

Fungos filamentosos tem sido alvo de estudos de bioprospecção devido à sua grande eficiencia em produzir enzimas extracelulares, as quais tem grande potencial para uso em bioindústrias. Neste estudo, fungos filamentosos foram isolados do intestino de larvas de insetos aquáticos da Amazônia, para avaliar sua atividade celulolítica. Foram coletadas 69 larvas de insetos aquáticos fragmentadores de três gêneros: Phylloicus (Trichoptera: Calamoceratidae), Triplectides (Trichoptera: Leptoceridae) e Stenochironomus (Diptera: Chironomidae) em dez igarapés de uma área protegida na Amazônia central brasileira. O crescimento dos fungos isolados foi feito em meio de cultura Ágar Batata Dextrose (BDA). Os isolados fúngicos foram transferidos para o meio sintético com Carboximetil celulose e utilizou-se vermelho Congo para determinar o índice enzimático. O halo de hidrólise, indicando a produção de celulases, foi observado em 175 isolados fúngicos ( $70 \%$ do total), dos quais 25 tiveram um índice enzimático $\geq 2,0$ e pertencem a sete gêneros fúngicos. Os táxons fúngicos Cladosporium, Gliocephalotrichum, Penicillium, Pestalotiopsis, Talaromyces, Trichoderma e Umbelopsis foram isolados dos intestinos das larvas de Phylloicus, Triplectides e Stenochironomus e são tradicionalmente utilizados em aplicaçóes biotecnológicas. Os resultados indicam um potencial celulolítco destes fungos associados ao intestino de insetos aquáticos amazônicos.

PALAVRas-CHAVE: celulase, hidrólise enzimática, Phylloicus, fragmentadores, Amazônia 


\section{INTRODUCTION}

Cellulases produced by fungi are widely used in industry, and the demand for efficient microorganisms has increased over time. Cellulases are currently employed in the production of food, animal feed, second generation ethanol, fruit and vegetable juices, paper, wine and textiles as well as in pulp extraction, starch processing, breweries, laundry and agriculture (Bhat 2000; Choi et al. 2015; Singh et al. 2016). Fungal enzymes are particularly advantageous when compared to animal or plant equivalents, as their production is less costly since the enzymes are secreted as complexes that work in synergy (Dashtban et al. 2009). Moreover, fungal enzymes have different physicochemical characteristics (e.g., thermostable enzymes of thermophilic organisms), and they are easier to produce on a large scale (Dalmaso et al. 2015).

Many insects that digest wood, foliage and debris (e.g., Isoptera, Coleoptera, Orthoptera, Hymenoptera) (Martin 1983) use lignocellulose as their main food source and are highly efficient in obtaining glucose from cellulose degradation (Sun and Zhou 2011). Naturally, wood-boring insects have been common subjects of studies aiming at the prospection of lignocellulolytic enzymes (Geib et al. 2010). In addition, aquatic leaf-mining Diptera larvae (Koroiva 2013) and other larvae of shredder insects (Rogers and Dora-Peterson 2010) have been considered as potential sources of lignocellulolytic enzymes for the second-generation biofuel industry (Cook and Dora-Peterson 2010; Huang et al. 2010). Although insects can produce endogenous cellulases (Watanabe and Tokuda 2010; Shelomi et al. 2014; Pothula et al. 2019), the polysaccharide hydrolysis is mainly performed by extracellular enzymes produced by microorganisms that colonize the digestive tracts of the insects, especially by fungi like Aspergillus Micheli ex Haller, Fusarium Link and Penicillium Link (Rojas-Jiménez and Hernández 2015). Several filamentous fungi, such as Cladosporium Link, Penicillium, and Trichoderma Persoon, have been found in the guts of Coleoptera and Diptera such as Silvanidae (Coleoptera) (David et al. 1974), Tenebrionidae (Coleoptera) (Prabha et al. 2011), Platypodidae (Coleoptera) (Henriques et al. 2009) and Culicidae (Diptera) (Fonseca et al. 2008; Pereira et al. 2009; Maketon et al. 2014). However, the evolution and dynamics of microorganism communities and their insect hosts are not yet fully understood (Bobay and Raymann 2019).

In general, microorganisms participate in the digestive processes of insects that have diets with nutritional deficiency, such as insects that feed on phloem or on complex molecules like cellulose (Watanabe and Tokuda 2010). Their capacity to degrade cellulose, in particular, is high and widely distributed among different taxa. For example, microorganisms associated with the digestive tracts of various termite species degrade cellulose and lignin, providing the insects with glucose and fatty acids that will be used as an energy source (Breznak
2002). In contrast to our understanding of insect gutassociated bacteria, which have been widely documented (e.g., Schaaf and Dettner 1997; Lundgren and Lehman 2010; Vojvodic et al. 2013), less is known about the relationships between insects and associated fungi (McCreadie et al. 2011; Shao et al. 2015). In freshwater environments, an elaborate symbiosis occurs in aquatic shredder insects. These insects feed on allochthonous organic matter (decaying wood and leaves) only after it has been conditioned, i.e., colonized by microorganisms, which convert this tissue into a more palatable food through extracellular enzymes (Gessner $e t a l$. 1999; Abelho 2001; Gulis and Bärlocher 2017).

In the Amazon region, where insect diversity is one of the highest in the world, knowledge on fungus-insect systems and cellulase-producing fungi associated with aquatic insects is still incipient (Rios-Velasquez et al. 2002; Alencar et al. 2003; Fonseca et al. 2008; Pereira et al. 2009; Santos et al. 2018a; Santos et al. 2018b). The study of the gut mycobiota of aquatic insects can lead to the discovery of metabolic processes and interactions with potential biotechnological applications. Thus, the aim of this study was to investigate the cellulase activity of filamentous fungi isolated from the gut of aquatic shredder insects, expecting to identify new cellulolytic enzymes in poorly studied species of Amazonian insects.

\section{MATERIAL AND METHODS}

\section{Collecting insects}

Larvae of aquatic shredder insects belonging to the genus Phylloicus Müller (Trichoptera: Calamoceratidae), Triplectides Kolenati (Trichoptera; Leptoceridae) and Stenochironomus Kieffer (Diptera: Chironomidae) were collected in ten forest streams located in the Adolpho Ducke Forest Reserve, municipality of Manaus, Amazonas state (Brazil) $\left(02^{\circ} 56^{\prime} 21^{\prime \prime} \mathrm{N}, 59^{\circ} 57^{\prime} 43^{\prime \prime} \mathrm{W}\right)$ (Figure 1). The stream beds are composed of sand and leaves, and the streams are shaded by riparian vegetation (e.g., Mendonça et al. 2005). The values of $\mathrm{pH}$ ranged from 4.4 to 5.4. The electrical conductivity of the water ranged from 7 to $23 \mu \mathrm{cm}^{-1}$, water velocity from 0.04 to $0.17 \mathrm{~cm} \mathrm{~s}^{-1}$, dissolved oxygen concentration from 5.8 to $6.8 \mathrm{mg} \mathrm{L}^{-1}$, and the water temperature ranged from 24.8 to $26.8^{\circ} \mathrm{C}$.

Insect larvae were collected randomly in August 2016 with the aid of an aquatic entomological net and identified to the genus level in the field according to Hamada et al. (2014). In total, we captured 69 larvae: 24 Phylloicus spp., 20 Triplectides spp., and 25 Stenochironomus spp. Each larva was removed from its shelter (leaf or stick), sterilized for 30 seconds in $70 \%$ ethanol, and stored in a microtube with sterile distilled water. Larvae were processed shortly after collection to avoid the decomposition or excretion of the contents of their digestive tracts. 


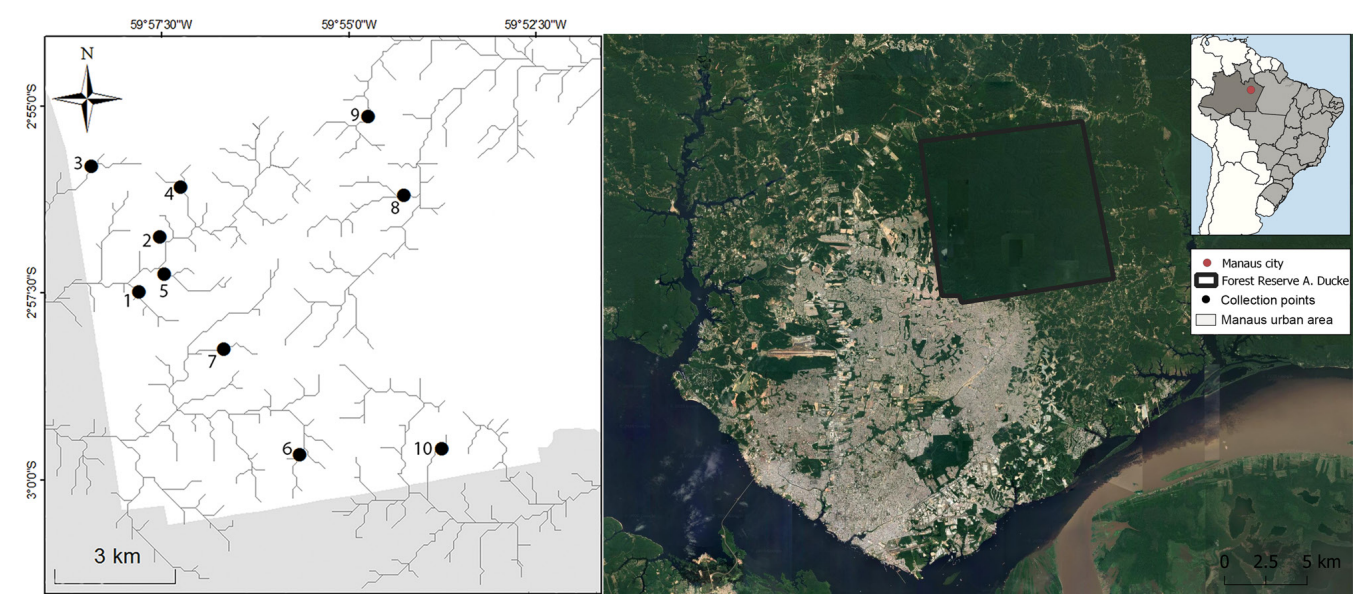

Figure 1. Location of the Adolpho Ducke Forest Reserve adjacent to the city of Manaus, Amazonas state, Brazil (satellite image and inset map). The outline map shows the southwestern portion of the Reserve with its stream outlines and the sampling sites of aquatic shredder insect larvae (1 to 10). This figure is in color in the electronic version.

\section{Isolation, purification and morphological characterization of filamentous fungi}

Larvae were dissected under a stereomicroscope using sterilized pins and scissors in the Laboratory of Citotaxonomy and Aquatic Insects of Instituto Nacional de Pesquisas da Amazônia - INPA. Each larva had its guts removed and transferred to a microtube containing $1 \mathrm{~mL}$ of sterile distilled water. After homogenizing, a $100 \mu \mathrm{L}$ aliquot of each sample was inoculated in a Petri dish containing Potato Dextrose Agar (PDA) medium supplemented with 0.1 mg L ${ }^{-1}$ chloramphenicol and incubated at $27{ }^{\circ} \mathrm{C}$ for seven days. For purification, the filamentous fungi that showed no contamination were transferred separately to new Petri dishes containing PDA. After obtaining pure fungal cultures, preservation was carried out by the Castellani method (Castellani 1939). Contaminated strains that were not recovered after the purification step were not considered in data analysis and they are not represented in the results. The fungal isolates were identified based on macromorphological characteristics such as color, shape, size, and border, among other relevant characteristics (Lacap et al. 2003; Ibrahim et al. 2017). To observe the micromorphological characteristics, the fungal isolates were microcultured, stained with lactophenol cotton blue and examined under a Leica Microsystems optical microscope with an attached Leica DFC295 camera and the Leica Application Suite (LAS, 4.2.0) software.

\section{Cellulolytic activity screening}

The fungal isolates were evaluated for cellulase production in carboxymethyl cellulose $(\mathrm{CMC})$ medium $\left(\mathrm{NaNO}_{3}: 3.0\right.$ $\mathrm{g} \mathrm{L}^{-1}$; $\mathrm{K}_{2} \mathrm{HPO}_{4}$ : $1.0 \mathrm{~g} \mathrm{~L}^{-1}$; $\mathrm{MgSO}_{4}$ : $0.5 \mathrm{~g} \mathrm{~L}^{-1}$; $\mathrm{KCl}: 0.5 \mathrm{~g} \mathrm{~L}^{-1}$; $\mathrm{FeSO}_{4} .7 \mathrm{H}_{2} \mathrm{O}: 10.0 \mathrm{mg} \mathrm{L}^{-1}$; CMC: $10.0 \mathrm{~g} \mathrm{~L}^{-1}$; agar: $20.0 \mathrm{~g}$ $\mathrm{L}^{-1}$ ) (Ruegger and Tauk-Tornisielo 2004). The plates were incubated at $27^{\circ} \mathrm{C}$ for four days and then subjected to thermal shock for $16 \mathrm{~h}$ at $50{ }^{\circ} \mathrm{C}$. The degradation halo was observed using $10 \mathrm{~mL}$ of Congo red solution $\left(2.0 \mathrm{~g} \mathrm{~L}^{-1}\right)$ for $30 \mathrm{~min}$ and $5 \mathrm{~mL}$ of $0.5 \mathrm{M} \mathrm{NaCl}$ solution in $0.1 \mathrm{M}$ Tris- $\mathrm{HCl}$ buffer, pH 8.0 (Nogueira and Cavalcante 1996). These assays were performed in triplicate. We calculated the enzymatic index (E.I.) of all isolates that produced a degradation halo. The E.I. was calculated as the ratio between the mean halo diameter and the mean colony diameter among the three replicates (Hankin and Anagnostakis 1975). The fungal isolates that had high enzymatic activity, here defined as E.I. $\geq 2.0$ (Lealem and Gashe 1994), were further identified by molecular analysis.

\section{Molecular analyses}

The fungal isolates were cultivated in natural potato broth for five days in a rotary shaker $(150 \mathrm{rpm})$ at $27^{\circ} \mathrm{C}$. DNA extraction was performed using a Fungi/Yeast Genomic DNA Isolation kit (Norgen Biotek, ON, CAN) following the manufacturer's instructions. The fungal ITS1-5.8S-ITS2 regions were amplified by PCR using the forward primer ITS1 5'-TCCGTAGGTGAACCTGCGG-3' and the reverse primer ITS4 5'-TCCTCCGCTTATTGATATGC-3' (White et al. 1990). Amplification was accomplished in a $50 \mu \mathrm{L}$ reaction mixture containing $2 \mu \mathrm{L}$ of genomic DNA, $0.3 \mu \mathrm{L}$ of Taq DNA polymerase - Platinum ${ }^{\oplus} 5 \mathrm{U} / \mu \mathrm{L}, 1.25 \mu \mathrm{L}$ of reaction buffer $(10 \times), 2.5 \mu \mathrm{L}$ of dNTPs ( $2.5 \mathrm{mM}$ each), 2.5 $\mu \mathrm{L}$ of $\mathrm{MgCl}(50 \mathrm{mM}), 0.5 \mu \mathrm{L}$ of each primer $(20 \mu \mathrm{M})$, and 15.95 $\mu \mathrm{L}$ of sterile Milli-Q water with the following reaction program: $94^{\circ} \mathrm{C}$ for $5 \mathrm{~min} ; 35$ cycles of denaturation at $94^{\circ} \mathrm{C}$ for $1 \mathrm{~min}$, annealing at $55^{\circ} \mathrm{C}$ for $1 \mathrm{~min}$, extension at $72^{\circ} \mathrm{C}$ for $1 \mathrm{~min}$ and final extension at $72^{\circ} \mathrm{C}$ for $5 \mathrm{~min}$. Amplicons were confirmed by electrophoresis on a $1.0 \%(\mathrm{w} / \mathrm{v})$ agarose gel, purified with GFX ${ }^{\mathrm{TM}}$ PCR and DNA Gel Band Purification Kit (GE Healthcare, USA) and sequenced following the BigDye $^{\oplus}$ V3.1 protocol in an ABI 3500 sequencer (Thermo Fisher Scientific, MA, USA). Analyses were carried out in 
the Molecular Biology Laboratory of Universidade Federal do Amazonas - UFAM.

\section{Taxonomy}

The consensus sequence of both DNA strands was obtained using Geneious ${ }^{\oplus}$ 9.0.5 (Kearse et al. 2012). The alignment of the consensus sequences was performed against the database of fungal genomes deposited in GenBank using the Basic Local Alignment Searching Tool (BLAST) (Altschul et al. 1990) of the National Center for Biotechnology Information (NCBI). In addition, the UNITE database was also used (Nilsson et al. 2018; https://unite.ut.ee/).

\section{RESULTS}

The intestinal content of 46 of the 69 aquatic insect larvae collected resulted in fungal growth (Table 1). A total of 248 fungi were isolated from the guts of Phylloicus, Triplectides and Stenochironomus larvae. Among these fungal isolates, 175 produced cellulases: 84 from guts of Phylloicus larvae, 55 from Triplectides larvae, and 36 from Stenochironomus larvae (Table 1). Out of the 175 isolates that produced cellulases, 25 had an E.I. $\geq 2.0$ (22.4\% of all fungi isolated from guts of Stenochironomus larvae, $8 \%$ of Triplectides and 6.2\% of Phylloicus) (Table 1).

Most of the identified fungal isolates were Eurotiomycetes, of which 15 were identified as Penicillium (Eurotiales: Aspergillaceae), with E.I. from 2.0 to 4.0. (A1TB1), which had been previously identified as Penicillium sp. based on morphology, but was assigned to Talaromyces purpurogenus (Stoll) Samson, Yilmaz, Frisvad and Seifert (Eurotiales: Trichocomaceae) based on molecular analysis (Table 2). Another representative group was Dothideomycetes, with six isolates identified as Cladosporium (Capnodiales: Davidiellaceae). Ascomycete was represented by one isolate of the genus Pestalotiopsis Steyaert (Xylariales: Sporocadaceae), and Sordariomycetes was represented by one isolate of the genus Trichoderma (Hypocreales: Hypocreaceae) (Table 2; Figure 2).

The molecular taxonomic identification confirmed most of our morphology-based identifications (Table 2). Five isolates

Table 1. Total number of fungal isolates and number of isolates positive for cellulolytic activity in aquatic shredder insects belonging to three genera sampled in Ducke Reserve, in the central Brazilian Amazon. E.I. = enzymatic index.

\begin{tabular}{lcccccc}
\hline \multirow{2}{*}{ Aquatic insect } & \multicolumn{2}{c}{ Number of insects } & & \multicolumn{3}{c}{$\begin{array}{c}\text { Number of fungal } \\
\text { isolates }\end{array}$} \\
\cline { 2 - 3 } \cline { 6 - 7 } & Total & $\begin{array}{c}\text { N with } \\
\text { fungal growth }\end{array}$ & & Total & Positive & E.l. $\geq 2.0$ \\
\hline Phylloicus spp. & 24 & 19 & & 112 & 84 & 7 \\
Triplectides spp. & 20 & 19 & & 87 & 55 & 7 \\
Stenochironomus spp. & 25 & 8 & & 49 & 36 & 11 \\
Total & 69 & 46 & & 248 & 175 & 25 \\
\hline
\end{tabular}

could be identified only to the genus level: Gliocephalotrichum Ellis and Hesseltine (Hypocrales: Nectriaceae) and

Umbelopsis Amos and Bernett (Mucorales: Umbelopsidaceae). Five isolates could be further identified to the species level: Trichoderma harzianum Rifai, Talaromyces purpurogenus, Penicillium adametzii Zalessky, and P. citrinum Thom.

\section{DISCUSSION}

Overall, we found that the guts of Phylloicus, Triplectides and Stenochironomus larvae analyzed in this study are colonized by Cladosporium, Gliocephalotrichum, Penicillium, Pestalotiopsis, Talaromyces Benjamin, Trichoderma and Umbelopsis fungi that have species that are traditionally used in biotechnological applications (Jalmi et al. 2012; CopetePertuz et al. 2019; Geetha et al. 2019; Liuzzi et al. 2019; Salazar-Cerezo et al. 2019; Ge et al. 2020; Slaný et al. 2020).

Interestingly, among the isolates with E.I. $\geq 2.0$, fungi of the genus Penicillium were more common and more efficient producers of cellulase in solid medium than Trichoderma, which is the most well-studied fungal group for cellulase, comprising very powerful decomposers of crystalline cellulose (Galliano et al. 1988; Ahamed and Vermette 2008; Gusakov 2011). Penicillium strains can be as good as Trichoderma strains in the production of cellulases, based on indicators such as production level and cellulase hydrolytic performance per unit of activity or per milligram of protein (Gusakov 2011; Syed et al. 2013; Carvalho et. al. 2014). More recently, Santos et al. (2018b) investigated the filamentous fungi isolated from the guts of Phylloicus larvae using both classical and molecular methods and found 21 isolates belonging to the genus Penicillium. Our study further corroborates the association between filamentous fungi and aquatic insect larvae.

Other fungal genera with known cellulolytic activity were isolated in this study. Gliocephalotrichum is commonly regarded as a saprophytic fungus (Lombard et al. 2014) and this is the first record of its association with insect guts. Umbelopsis, which here produced cellulases in a solid medium with carboxymethyl cellulose, colonizes substrates rich in simple carbohydrates and has been found associated with Curculionidae insects (Silva et al. 2015). Talaromyces is also known to be associated with insects such as Cynipidae (Hymenoptera) (Seifert et al. 2004) and has been recorded in the midguts of Aedes aegypti (Diptera) (Angleró-Rodríguez et al. 2017). Some species of Talaromyces (T. emersonii CBS 814.70 and T. cellulolyticus Fujii) are able to produce cellulolytic enzymes (Inoue et al. 2014). Talaromyces purpurogenus, which is important in bioindustry due to its ability to produce cellulolytic enzymes (Belancic et al. 1995), was recently placed in the genus Penicillium (Samson et al. 2011), and Talaromyces received all species of the Penicillium 
Table 2. Cellulolytic filamentous fungi isolated from the guts of Phylloicus (Trichoptera), Triplectides (Trichoptera) and Stenochironomus (Diptera) shredder aquatic insects, in the central Amazon region of Brazil. The table shows the morphological and molecular identification of the isolates that had an enzymatic index $\geq 2.0$ after growing on a synthetic carboxymethylcellulose medium. $M=$ morphological identification; $G=$ molecular genotyping; E.I. = enzymatic index (mean index $\pm S D, n=$ 3); $\left({ }^{*}\right)=$ percentage of similarity between our sequences and those available in the NCBI and UNITE databases.

\begin{tabular}{|c|c|c|c|c|c|c|c|}
\hline Sample \# & Host insect & $\begin{array}{l}\text { Fungal } \\
\text { isolate }\end{array}$ & Species & $\begin{array}{c}\text { Type of } \\
\text { identification }\end{array}$ & E.I. & Identity* & $\begin{array}{c}\text { Accession } \\
\text { number }\end{array}$ \\
\hline 1 & Phylloicus & A1PA3 & Cladosporium sp. & M & $2.3 \pm 0.3$ & & \\
\hline 2 & Phylloicus & A1PB5 & Pestalotiopsis sp. & G & $3.1 \pm 0.8$ & $97 \%$ & KF887030.1 \\
\hline 4 & Phylloicus & A2PA4 & Penicillium sp. & G & $3.9 \pm 0.2$ & $99 \%$ & JQ889696.1 \\
\hline 5 & Phylloicus & $\mathrm{A} 2 \mathrm{PC} 2$ & Cladosporium sp. & G & $2.8 \pm 0.5$ & $87 \%$ & MH655007.1 \\
\hline 11 & Phylloicus & A5PA3 & Gliocephalotrichum sp. & G & $2.9 \pm 0.4$ & $94 \%$ & MH397480.1 \\
\hline 17 & Phylloicus & A8PB5 & Penicillium sp. & M & $2.1 \pm 0.2$ & & \\
\hline 20 & Phylloicus & A9PB4 & Trichoderma harzianum & G & $2.3 \pm 0.1$ & $100 \%$ & MN262498.1 \\
\hline 2 & Triplectides & A1TB1 & Talaromyces purpurogenus & G & $3.0 \pm 0.0$ & $99 \%$ & MK108916.1 \\
\hline 2 & Triplectides & A1TB3 & Penicillium sp. & G & $2.0 \pm 0.4$ & $97 \%$ & MK775828.1 \\
\hline 8 & Triplectides & A4TA1 & Penicillium sp. & M & $2.8 \pm 0.3$ & & \\
\hline 8 & Triplectides & A4TA3 & Umbelopsis sp. & G & $3.7 \pm 0.5$ & $98 \%$ & MF101390.1 \\
\hline 17 & Triplectides & A8TA5 & Penicillium adametzii & G & $4.0 \pm 0.6$ & $99 \%$ & JN714932.1 \\
\hline 17 & Triplectides & A8TA7 & Penicillium sp. & G & $3.9 \pm 0.4$ & $94 \%$ & KF848945.1 \\
\hline 17 & Triplectides & A8TA9 & Penicillium sp. & G & $2.5 \pm 0.0$ & $93 \%$ & MH268036.1 \\
\hline 3 & Stenochironomus & $\mathrm{A} 1 \mathrm{SC} 3$ & Penicillium sp. & G & $2.5 \pm 0.1$ & $85 \%$ & KC181929.1 \\
\hline 4 & Stenochironomus & $\mathrm{A} 2 \mathrm{SA} 2$ & Penicillium sp. & M & $2.1 \pm 0.8$ & & \\
\hline 4 & Stenochironomus & A2SA4 & Penicillium sp. & M & $2.8 \pm 0.8$ & & \\
\hline 4 & Stenochironomus & A2SA5 & Penicillium sp. & M & $2.2 \pm 0.1$ & & \\
\hline 5 & Stenochironomus & A2SB2 & Cladosporium sp. & M & $2.0 \pm 0.5$ & & \\
\hline 5 & Stenochironomus & A2SB3 & Penicillium adametizii & G & $2.0 \pm 0.3$ & $99 \%$ & JN714932.1 \\
\hline 7 & Stenochironomus & A3SA1 & Cladosporium sp. & M & $3.1 \pm 0.5$ & & \\
\hline 8 & Stenochironomus & A4SA1 & Penicillium sp. & G & $2.3 \pm 0.1$ & $97 \%$ & MN238763.1 \\
\hline 10 & Stenochironomus & $\mathrm{A} 4 \mathrm{SC} 2$ & Penicillium citrinum & G & $2.1 \pm 0.4$ & $99 \%$ & KM278038.1 \\
\hline 12 & Stenochironomus & A5SB3 & Cladosporium sp. & M & $2.5 \pm 0.1$ & & \\
\hline 13 & Stenochironomus & $\mathrm{A} 5 \mathrm{SC} 1$ & Cladosporium sp. & M & $2.9 \pm 0.4$ & & \\
\hline
\end{tabular}

subgenus Biverticillium (Samson et al. 2011), since these two taxa form a monophyletic group (Yilmaz et al. 2014).

Our results expand the knowledge on the diversity and functions of fungi associated with the guts of aquatic insects, since few similar studies have been carried out with Amazonian species. Santos et al. (2018b) identified fungi isolated from the gut of Phylloicus larvae in from the Brazilian states of Pará and Tocantins, in the Amazonian and Cerrado savanna biomes, respectively, thus suggesting the occurrence of distinct associated fungi communities across ecosystems. While there are studies on fungi associated with insects, studies on the gut microbiome are lacking (e.g., Fonseca et al. 2008; Pereira et al. 2009). Moreover, studies on the gut mycobiota of aquatic insects in Amazonia have been concentrated on the class
Trichomycetes (e.g., Rios-Velásquez et al. 2002; Alencar et al. 2003).

Our results suggest that the mycobiota of aquatic shredder insect guts isolated in this study can effectively degrade cellulose. The presence of cellulolytic fungi is probably related to the conditioning of ingested leaf material through the decomposition of structural compounds by fungal enzymes, which softens the material and increases the palatability of the leaves (Graça et al. 2001; Aßmann et al. 2011; Casotti et al. 2015; Biasi et al. 2017; Reis et al. 2018). Graça et al. (2001) demonstrated experimentally that insects preferred conditioned leaves over unconditioned leaves. Likewise, Reis et al. (2018) showed that high concentrations of tannins in unconditioned leaves are inhibitory and not consumed by 

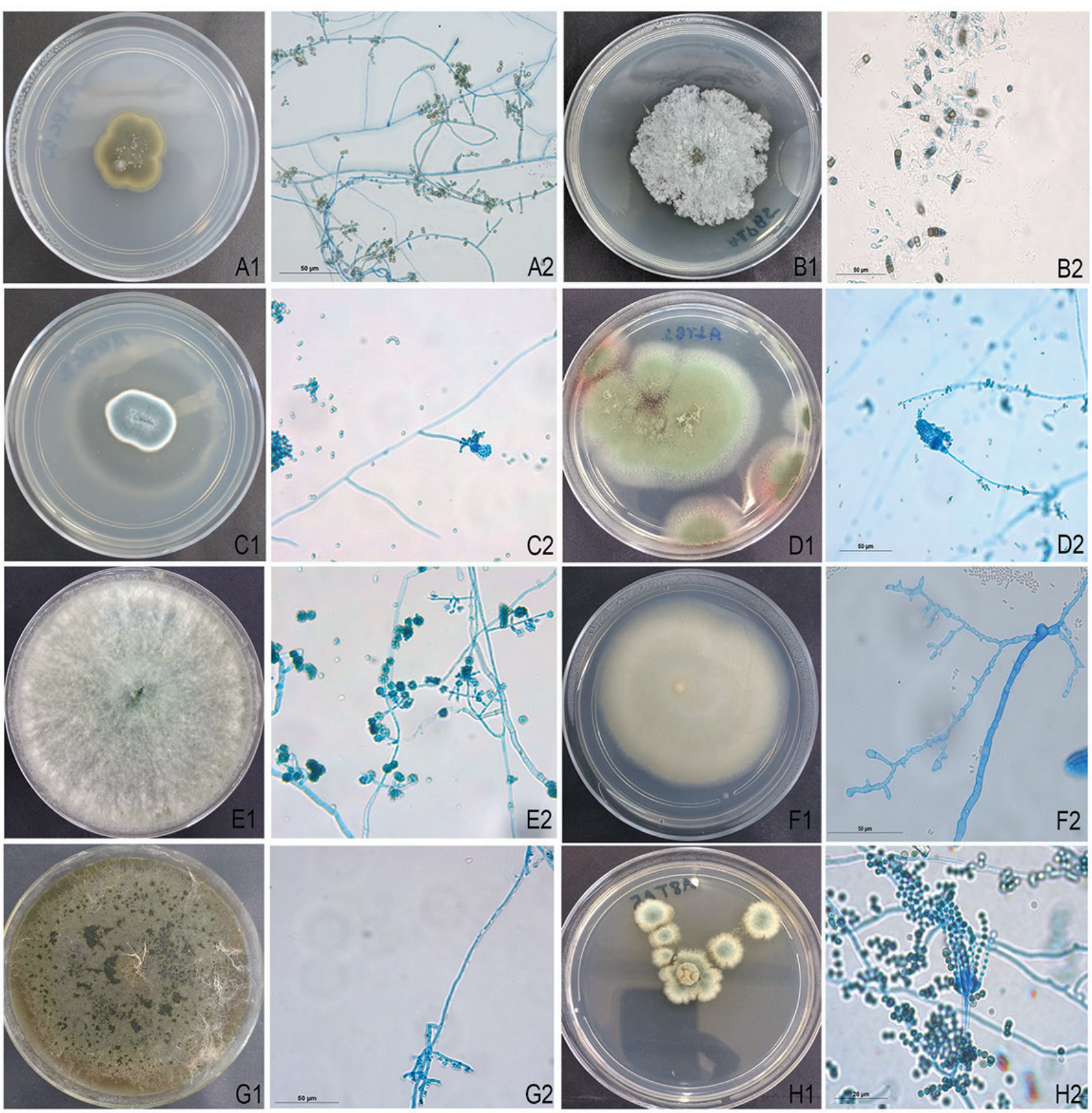

Figure 2. Macro and microscopic views of filamentous fungi isolated from the guts of Phylloicus (Trichoptera), Triplectides (Trichoptera) and Stenochironomus (Diptera) plated in PDA medium for seven days at $27^{\circ} \mathrm{C}$. A1/A2 - Cladosporium sp.; B1/B2 - Pestalotiopsis sp.; C1/C2 - Penicillium citrinum; D1/D2 - Talaromyces purpurogenus; E1/E2 - Trichoderma harzianum; F1/F2 - Umbelopsis sp.; G1/G2 - Gliocephalotrichum sp.; H1/H2 - Penicillium adametzii. This figure is in color in the electronic version.

insect larvae. Gonçalves-Júnior et al. (2017) compared the characteristics of five common leaves found in streams in the Adolpho Ducke Forest Reserve and noted that shredder insects were more frequent on the leaves of Mabea speciosa Müll.Arg (Euphorbiaceae), which had a higher polyphenol content, lower amount of cellulose and higher concentration of fungal biomass than the leaves of the other plants. These results indicate that aquatic shredder insect larvae feed on leaves conditioned by fungi, which initiate the decomposition process through extracellular enzymes, facilitating digestion by the larvae (Graça et al. 2001; Aßmann et al. 2011; Casotti et al. 2015; Biasi et al. 2017; Reis et al. 2018).

\section{CONCLUSIONS}

This study contributes to the knowledge of the mycobiota associated with the guts of aquatic insect larvae, however it remains elusive to what extent the fungal microbiota 
influences its host life's. Overall, we expect that future research on shredder aquatic insects microbiota will contribute to our understanding of interactions fungi-host. The presence of cellulolytic fungi in the guts of aquatic insects reinforces the biotechnological potential for cellulolytic-enzyme prospection. Our study also brings new information on the identities and functional traits of the symbiotic fungi of aquatic-insects in the Amazon that have not been previously studied. As available data about symbionts increase, so does the understanding of the ecological relationships between these fungi and their insect hosts. More research is essential to better understand the processes that occur in the fungus-insect system, in addition to the biotechnological potential of these processes.

\section{ACKNOWLEDGMENTS}

This research was supported by grant \# 407843/2013-2 from Conselho Nacional de Desenvolvimento Científico e Tecnológico (CNPq), Ministério da Ciência, Tecnologia, Inovaçôes e Comunicaçóes - Fundo Nacional de Desenvolvimento Científico e Tecnológico - Ação Transversal - Redes Regionais de Pesquisa em Ecossistemas, Biodiversidade e Biotecnologia and, in part, by INCT ADAPTA II/ CNPq (proc. \# 465540/2014-7), Fundação de Amparo à Pesquisa do Estado do Amazonas - FAPEAM (proc. \# 062.1187/2017) and Coordenaçáo de Aperfeiçoamento de Pessoal de Nível Superior - CAPES. ELBM received a PhD fellowship from CNPq (proc. \# 141267/2016-0) and NH is a CNPq research fellow (proc. \# 307849/ 2014-7).

\section{REFERENCES}

Abelho, M. 2001. From litterfall to breakdown in streams: a review. The Scientific World Journal, 1: 656-680.

Ahamed, A.; Vermette, P. 2008. Culture-based strategies to enhance cellulase enzyme production from Trichoderma reesei RUT-C30 in bioreactor culture conditions. Biochemical Engineering Journal, 40: 399-407.

Alencar, Y.B.; Rios-Velásquez C.M.; Lichtwardt R.W.; Hamada N. 2003. Trichomycetes (Zygomycota) in the digestive tract of arthropods in Amazonas, Brazil. Memórias do Instituto Oswaldo Cruz, 98: 799-810.

Altschul, S.F.; Gish W.; Miller W.; Myers, E.W. 1990. Basic local alignment search tool. Journal of Molecular Biology, 215: 403-410.

Angleró-Rodríguez, Y.I.; Talyuli, O.A.C.; Blumberg, B.J.; Kang, S.; Demby, C.; Shields, A.; Carlson, J.; Jupatanakul, N.; Dimopoulos, G. 2017. An Aedes aegypti-associated fungus increases susceptibility to dengue virus by modulating gut trypsin activity. eLife, 6: 1-20.

Aßmann, C.; Rinke K.; Nechwatal J.; Elert E. V. 2011. Consequences of the colonisation of leaves by fungi and oomycetes for leaf consumption by a gammarid shredder. Freshwater Biology, 56: 839-852.
Belancic, A.; Scarpa J.; Peirano A.; Diaz R. 1995. Penicillium purpurogenum produces several xylanases: Purification and properties of two of the enzymes. Journal of Biotechnology, 41: 71-79.

Bhat, M.K. 2000. Cellulases and related enzymes in biotechnology. Biotechnology Advances, 18: 355-383.

Biasi, C.; Graça M.A.S.; Santos, S.; Ferreira, V. 2017. Nutrient enrichment in water more than in leaves affects aquatic microbial litter processing. Oecologia, 184: 555-568.

Bobay, L.M.; Raymann, K. 2019. Population genetics of hostassociated microbiomes. Current Molecular Biology Reports, 5: 128-139.

Breznak, J.A. 2002. Phylogenetic diversity and physiology of termite gut spirochetes. Integrative and Comparative Biology. 42: 13-18.

Carvalho, M.L.A.; Carvalho, D.F.; Gomes, E.D.; Maeda, R.N.; Anna, L.M.M.S; Castro, A.M.; Pereira-Júnior, N. 2014. Optimization of cellulase production by Penicillium funiculosum in stirred tank bioreactor using multivariate response surface analysis. Enzyme Research, 2014: 1-8.

Casotti, C.G.; Kiffer-Junior, W.P.; Costa, L.C.; Rangel, J.V.; Casagrande, L.C.; Moretti, M.S. 2015. Assessing the importance of riparian zones conservation for leaf decomposition in streams. Natureza \& Conservação, 13: 178-182.

Castellani, A. 1939. The viability of some pathogenic fungi in sterile distilled water. The American Journal of Tropical Medicine and Hygiene, 42: 65-72.

Choi, J.M.; Han, S.S.; Kim, H.S. 2015. Industrial applications of enzyme biocatalysis: Current status and future. Biotechnology Advances, 33: 1443-1454.

Cook, D.M.; Doran-Peterson, J. 2010. Mining diversity of the natural biorefinery housed within Tipula abdominalis larvae for use in an industrial biorefinery for production of lignocellulosic ethanol. Insect Science, 17: 303-312.

Copete-Pertuz, L.S; Alandete-Novoa, F.; Plácido, J.; CorreaLondoño, G.A.; Mora-Martínez, A.L. 2019. Enhancement of ligninolytic enzymes production and decolourising activity in Leptosphaerulina sp. by co-cultivation with Trichoderma viride and Aspergillus terréus. Science of the Total Environment, 646: 1536-1545.

Dalmaso, G.Z.; Ferreira, D.; Vermelho, A.B. 2015. Marine extremophiles: A source of hydrolases for biotechnological applications. Marine Drugs, 13: 1925-1965.

Dashtban, M.; Schraft, H.; Qin, W. 2009. Fungal bioconversion of lignocellulosic residues: opportunities and perspectives. International Journal of Biological Sciences, 5: 578-595.

David, M.H.; Mills, R.B.; Sauer, D.B. 1974. Development and oviposition of Ahasverus advena (Coleoptera: Silvanidae) on seven species of fungi. Journal of Stored Products Research, 10: 17-22.

Fonseca, Q.R.; Sarquis, M.I.M.; Hamada, N.; Alencar, Y.B. 2008 Occurrence of filamentous fungi in Simulium goeldii Cerqueira \& Nunes de Mello (Diptera: Simuliidae) larvae in Central Amazonia, Brazil. Brazilian Journal of Microbiology, 39: 282-285.

Galliano, H.; Gas, G.; Durand, H. 1988. Lignocellulose biodegradation and ligninase excretion by mutant strains 
of Phanerochaete chrysosporium hyperproducing cellulases. Biotechnology Letters, 10: 655-660.

Ge, J.; Jiang, X.; Liu, W.; Wang, Y.; Huang, H.; Bai, Y.; Su, X.; Yao, B.; Luo, H. 2020. Characterization, stability improvement, and bread baking applications of a novel cold-adapted glucose oxidase from Cladosporium neopsychrotolerans SL16. Food Chemistry, 310: 125970.

Geetha, K.S.; Shanthi Kumari, B.S.; Dileep Kumar, K.; Krushna Naik, S.N. 2019. Influence of organophosphorus pesticides on activities of antioxidant enzymes by Pestalotiopsis microspora TKBRR. International Journal of Research and Analytical Reviews, 6: 650-660.

Geib, S.M.; Tien, M.; Hoover, K. 2010. Identification of proteins involved in lignocellulose degradation using in gel zymogram analysis combined with mass spectroscopy-based peptide analysis of gut proteins from larval asian longhorned beetles, Anoplophora glabripennis. Insect Science, 17: 253-264.

Gessner, M.O.; Chauvet, E.; Dobson, M. 1999. A perspective on leaf litter breakdown in streams. Oikos, 85: 377-383.

Gonçalves-Jr, J.F.; Couceiro, S.R.M.; Rezende, R.S.; Martins, R.T.; Ottoni-Boldrini, B.M.P.; Campos, C.M.; Silva, J.O.; Hamada, N. 2017. Factors controlling leaf litter breakdown in Amazonian streams. Hydrobiologia, 792: 195-207.

Graça, M.A.S.; Cressa, C.; Gessner, M.O.; Feio, M.J.; Callies, K.A.; Barrios, C. 2001. Food quality, feeding preferences, survival and growth of shredders from temperate and tropical streams. Freshwater Biology, 46: 947-957.

Gulis, V.; Bärlocher, F. 2017. Fungi: biomass, production, and community structure. In: Hauer, F.R.; Lamberti, G.A. (Ed.). Methods in Stream Ecology. v.1. Academic Press, San Diego, p.177-192.

Gusakov, A.V. 2011. Alternatives to Trichoderma reesei in biofuel production. Trends in Biotechnology, 29: 419-425.

Hamada, N.; Nessimian, J.L.; Querino, R.B. 2014. Insetos Aquáticos na Amazônia Brasileira: Taxonomia, Biologia e Ecologia. Editora INPA, Manaus, 274p.

Hankin, L.; Anagnostakis, S.L. 1975. The use of solid media for detection of enzymes production by fungi. Mycologia, 67: 597-607.

Henriques, J.; Inacio, M.L.; Sousa, E. 2009. Fungi associated to Platypus cylindrus Fab. (Coleoptera: Platypodidae) in cork oak. Revista Ciências Agrárias, 32: 55-56.

Huang, S.W.; Zhang, H.Y.; Marshall, S.; Jackson, T.A. 2010. The scarab gut: A potential bioreactor for bio-fuel production. Insect Science, 17: 175-183.

Ibrahim, M.; Sieber, T.N.; Schlegel, M. 2017. Communities of fungal endophytes in leaves of Fraxinus ornus are highly diverse. Fungal Ecology, 29: 10-19.

Inoue, H., Decker, S.R.; Taylor, L.E.; Yano, S.; Sawayama, S. 2014. Identification and characterization of core cellulolytic enzymes from Talaromyces cellulolyticus (formerly Acremonium cellulolyticus) critical for hydrolysis of lignocellulosic biomass. Biotechnology for Biofuels, 7: 1-13.

Jalmi, P.; Bodke, P.; Wahidullah, S.; Raghukumar, S. 2012. The fungus Gliocephalotrichum simplex as a source of abundant, extracellular melanin for biotechnological applications. World Journal of Microbiology and Biotechnology, 28: 505-512.

Kearse, M.; Moir, R.; Wilson, A.; Stones-Havas, S.; Cheung, M.; Sturrock, S. et al. 2012. Geneious basic: an integrated and extendable desktop software platform for the organization and analysis of sequence data. Bioinformatics, 28: 1647-1649.

Koroiva, R.; Souza, C.W.O.; Toyama, D.; Henrique-Silva, F.; Fonseca-Gessner, A.A. 2013. Lignocellulolytic enzymes and bacteria associated with the digestive tracts of Stenochironomus (Diptera: Chironomidae) larvae. Genetics and Molecular Research, 12: 3421-3434.

Lacap, D.C.; Hyde, K.D.; Liew, E.C.Y. 2003. An evaluation of the fungal 'morphotype' concept based on ribosomal DNA sequences. Fungal Diversity, 12: 53-66.

Lealem, F.; gashe, B.A. 1994. Amylase production by a gram-prositive bacterium isolated from fermenting tef (Eraglostis tef). Journal of Applied Bacteriology, 77: 348-352.

Liuzzi, F.; Mastrolitti, S.; De Bari, I. 2019. Hydrolysis of corn stover by Talaromyces cellulolyticus enzymes: evaluation of the residual enzymes activities through the process. Applied Biochemistry and Biotechnology, 188: 690-705.

Lombard, L.; Serrato-Diaz, L.M.; Cheewangkoon, R.; FrenchMonar, R.D.; Decock, C.; Crous, P.W. 2014. Phylogeny and taxonomy of the genera Gliocephalotrichum. Persoonia, 32: $127-140$.

Lundgren, J.G.; Lehman, R.M. 2010. Bacterial gut symbionts contribute to seed digestion in an omnivorous beetle. PLoS ONE, 5: e10831.

Maketon, M.; Amnuaykanjanasin, A.; Kaysorngup, A. 2014. A rapid knockdown effect of Penicillium citrinum for control of the mosquito Culex quinquefasciatus in Thailand. World Journal of Microbiology and Biotechnology, 30: 727-736.

Martin, M.M. 1983. Cellulose digestion in insects. Comparative Biochemistry and Physiology B, 75A: 313-324.

McCreadie, J.W.; Adler, P.H.; Beard, C.E. 2011. Ecology of symbiotes of larval black flies (Diptera: Simuliidae): distribution, diversity, and scale. Environmental Entomology, 40: 289-302.

Mendonça, F.P.; Magnusson, W.E.; Zuanon, J. 2005. Relationships between habitat characteristics and fish assemblages in small streams of Central Amazonia. Copeia, 4: 751-764.

Nilsson, R.H.; Larsson, K.H.; Taylor, A.F.S.; Bengtsson-Palme, J.; Jeppesen, T.S.; Schigel, D. et al. 2018. The UNITE database for molecular identification of fungi: handling dark taxa and parallel taxonomic classifications. Nucleic Acids Research, 1-6: 178-182.

Nogueira, E.B.S.; Cavalcanti, M.A.Q. 1996. Cellulolytic fungi isolated from processed oats. Revista de Microbiologia, 27: 7-9.

Pereira, E.D.S.; Sarquis, M.I.M.; Ferreira-Keppler, R.L.; Hamada, N.; Alencar, Y.B. 2009. Filamentous fungi associated with mosquito larvae (Diptera: Culicidae) in municipalities of the Brazilian Amazon. Neotropical Entomology, 38: 352-359.

Pothula, R.; Shirley, D.; Perera, O.P.; Klingeman, W.E.; Oppert, C.; Abdelgaffar, H.M.Y.; Johnson, B.R.; Jurat-Fuentes, J.L. 2019. The digestive system in Zygentoma as an insect model for high cellulase activity. PLoS ONE, 14:1-16. 
Prabha, K.C.; Sivadasan, R.; Jose, A. 2011. Microflora associated with the red flour beetle, Tribolium castaneum (Coleoptera: Tenebrionidae). International Journal of Agricultural Technology, 7: 1625-1631.

Reis, D.F.; Machado, M.M.D.; Coutinho, N.P.; Rangel, J.V.; Morettican, M.S; Morais, P.B. 2018. Feeding preference of the shredder Phylloicus sp. for plant leaves of Chrysophyllum oliviforme or Miconia chartacea after conditioning in streams from different biomes. Brazilian Journal of Biology, 79: 22 -28.

Rios-Velásquez, C.M.; Hamada, N. 2002. Trichomycete fungi (Zygomycota) associated with the digestive tract of Simulium goeldii Cerqueira \& Nunes de Mello and Simulium ulyssesi (PyDaniel \& Coscarón) (Diptera: Simuliidae) larvae, in Central Amazônia, Brazil. Memórias do Instituto Oswaldo Cruz, 97: 423-426.

Rogers, T.E.; Doran-Peterson, J. 2010. Analysis of cellulolytic and hemicellulolytic enzyme activity within the Tipula abdominalis (Diptera: Tipulidae) larval gut and characterization of Crocebacterium ilecola gen. nov. sp. nov., isolated from the Tipula abdominalis larval hindgut. Insect Science, 17: 291-302.

Rojas-Jimenez, K.; Hernandez, M. 2015. Isolation of fungi and bacteria associated with the guts of tropical wood-feeding Coleoptera and determination of their lignocellulolytic activities. International Journal of Medical Microbiology, 2015: 285018.

Ruegger, M.J.S.; Tauk-Tornisielo, S.M. 2004. Atividade da celulase de fungos isolados do solo da Estaçáo Ecológica de Juréia-Itatins, São Paulo, Brasil. Revista Brasileira de Botânica, 27: 205-211.

Salazar-Cerezo, S.; Kun, R.S.; Vries, R.P.; Garrigues, S. 2020. CRISPR/Cas9 technology enables the development of the filamentous ascomycete fungus Penicillium subrubescens as a new industrial enzyme producer. Enzyme and Microbial Technology, 133: 109463.

Samson, R.A.; Yilmaz, N.; Houbraken, J.; Spierenburg, H.; Seifert, K.A.; Peterson, S.W.; Varga, J.; Frisvad, J.C. 2011. Phylogeny and nomenclature of the genus Talaromyces and taxa accommodated in Penicillium subgenus Biverticillium. Studies in Mycology, 70: 159- 184 .

Santos, T.T.; Oliveira, D.P.; Cabette, H.S.R.; Morais, P.B. 2018a. The digestive tract of Phylloicus (Trichoptera: Calamoceratidae) harbours different yeast taxa in Cerrado streams, Brazil. Symbiosis, 77: 147-160.

Santos, T.T.; Oliveira, K.A.; Vital, M.J.S.; Couceiro, S.R.M.; Morais, P.B. 2018b. Filamentous fungi in the digestive tract of Phylloicus larvae (Trichoptera: Calamoceratidae) in streams of the Brazilian Amazon. Boletim do Museu Paraense Emílio Goeldi, 13:317-325.

Schaaf, O.; Dettner, K. 1997. Microbial diversity of aerobic heterotrophic bacteria inside the foregut of two tyrphophilous water beetle species (Coleoptera: Dytiscidae). Microbiological Research, 152: 57-64.
Seifert, K.A.; Hoekstra, E.S.; Frisvad, J.C.; Louis-Seize, G. 2004. Penicillium cecidicola, a new species on cynipid insect galls on Quercus pacifica in the western United States. Studies in Mycology, 50: 517-523.

Shao, M.W.; Lu, Y.H.; Miao, S.; Zhang, Y.; Chen, T-T.; Zhang, Y-L. 2015. Diversity, bacterial symbionts and antibacterial potential of gut-associated fungi isolated from the Pantala flavescens larvae in China. PloS One, 10: e0134542.

Shelomi, M.; Watanabe, H.; Arakawa, G. 2014. Endogenous cellulase enzymes in the stick insect (Phasmatodea) gut. Journal of Insect Physiology, 60: 25-30.

Silva, X.; Terhonena, E.; Suna, H.; Kasanenab, R.; Heliövaaraa, K.; Jalkanenc, R.; Asiegbua, F.O. 2015. Comparative analyses of fungal biota carried by the pine shoot beetle (Tomicus piniperda L.) in Northern and Southern Finland. Scandinavian Journal of Forest Research, 30: 497-506.

Singh, R.; Kumar, M.; Mittal, A.; Mehta, P.K. 2016. Microbial enzymes: industrial progress in 21 st century. Biotechnology Journal, 6: 1-15.

Slaný, O.; Klempová, T.; Marcinčák, S.; Čertík, M. 2020. Production of high-value bioproducts enriched with $\gamma$-linolenic acid and $\beta$-carotene by filamentous fungi Umbelopsis isabellina using solid-state fermentations. Annals of Microbiology, 70: 1-11.

Sun, J.Z.; Zhou, X.G. 2011. Utilization of lignocelluloses feeding insects for viable biofuels: an emerging and promising area of entomological science. In: Liu, T.; Kang, L. (Ed.). Recent Advances in Entomological Research: From Molecular Biology to Pest Management. Springer, Heidelberg and Berlin, p.251-291.

Syed, S.; Riyaz-Ul-Hassan, S.; Johri, S. 2013. A novel cellulase from endophtye, Penicillium sp. NFCC 286. American Journal of Microbiological Research, 1: 84-91.

Vojvodic, S.; Rehan, S.M.; Anderson, K.E. 2013. Microbial gut diversity of africanized and european honey bee larval instars. PLoS One, 8: e72106.

Watanabe, H.; Tokuda, G. 2010. Cellulolytic systems in insects. Annual Review of Entomology, 55: 609-632.

White, T.J., Bruns, T.; Lee, S.; Taylor, J. 1990. Amplification and direct sequencing of fungal ribosomal RNA genes for phylogenetics. In: Innis, M.A.; Gelfand, D.H.; Sninsky, J.J.; White T.J. (Ed.). PCR Protocols. Academic Press, London, p.315-322.

Yilmaz, N.; Visagie, C.M.; Houbraken, J.; Frisvad, J.C.; Samson, R.A. 2014. Polyphasic taxonomy of the genera Talaromyces. Studies in Mycology, 78: 175-341.

RECEIVED: $11 / 04 / 2020$

ACCEPTED: 09/08/2020

ASSOCIATE EDITOR: Valdir F. Veiga Junior 